\title{
Characteristics and conditions of production of transient luminous events observed over a maritime storm
}

Soula, S.; van der Velde, O.; Palmiéri, J.; Chanrion, Olivier Arnaud; Neubert, Torsten; Montanyà, J.; Gangneron, F.; Meyerfeld, Y.; Lefeuvre, F.; Lointier, G.

Published in:

Journal of Geophysical Research: Atmospheres

Link to article, DOI:

10.1029/2009JD012066

Publication date:

2010

Document Version

Publisher's PDF, also known as Version of record

Link back to DTU Orbit

Citation (APA):

Soula, S., van der Velde, O., Palmiéri, J., Chanrion, O. A., Neubert, T., Montanyà, J., Gangneron, F., Meyerfeld, Y., Lefeuvre, F., \& Lointier, G. (2010). Characteristics and conditions of production of transient luminous events observed over a maritime storm. Journal of Geophysical Research: Atmospheres, 115, D16118.

https://doi.org/10.1029/2009JD012066

\section{General rights}

Copyright and moral rights for the publications made accessible in the public portal are retained by the authors and/or other copyright owners and it is a condition of accessing publications that users recognise and abide by the legal requirements associated with these rights.

- Users may download and print one copy of any publication from the public portal for the purpose of private study or research.

- You may not further distribute the material or use it for any profit-making activity or commercial gain

- You may freely distribute the URL identifying the publication in the public portal 


\title{
Characteristics and conditions of production of transient luminous events observed over a maritime storm
}

\author{
S. Soula, ${ }^{1}$ O. van der Velde, ${ }^{2}$ J. Palmiéri, ${ }^{1}$ O. Chanrion, ${ }^{3}$ T. Neubert, ${ }^{3}$ J. Montanyà, ${ }^{2}$ \\ F. Gangneron, ${ }^{1}$ Y. Meyerfeld, ${ }^{1}$ F. Lefeuvre, ${ }^{4}$ and G. Lointier ${ }^{4}$ \\ Received 16 March 2009; revised 19 February 2010; accepted 31 March 2010; published 27 August 2010.
}

[1] On the night of 15/16 November 2007, cameras in southern France detected 30 transient luminous events (TLEs) over a storm located in the Corsican region (France). Among these TLEs, 19 were sprites, 6 were halos, and 5 were elves. For 26 of them, a positive "parent" cloud-to-ground lightning $(\mathrm{P}+\mathrm{CG})$ flash was identified. The peak current of the $\mathrm{P}+\mathrm{CG}$ flashes for the sprites had an average value of $63 \mathrm{kA}$ and had a maximum value of $125 \mathrm{kA}$. The flashes for the halos and the elves had average values of 272 and $351 \mathrm{kA}$, respectively, and they had maximum values of 312 and $384 \mathrm{kA}$, respectively. No TLEs were detected after negative CG flashes with very large peak currents. Among the $26 \mathrm{P}+\mathrm{CG}$ flashes, 23 were located in a stratiform region with reflectivity values lower than $45 \mathrm{dBZ}$. The $\mathrm{CG}$ flashes in this region were classified into two groups according to the time interval separating them from the following flash: one group with values less than $2 \mathrm{~s}$ and one with values greater than $2 \mathrm{~s}$. About $79 \%$ of all CGs were produced in a sequence of at least two flashes less than $2 \mathrm{~s}$ apart. For $65.5 \%$ of the sequences, the first flash was positive with an average peak current of $73 \mathrm{kA}$, while the later $+\mathrm{CG}$ flashes in a sequence had much lower peak currents. Several triangulated sprites were found to be shifted from their P+CG flashes by about 10 to $50 \mathrm{~km}$ and preferentially downstream. The observations suggest that the $\mathrm{P}+\mathrm{CG}$ flashes can initiate both sprites and other CG flashes in a storm.

Citation: Soula, S., O. van der Velde, J. Palmiéri, O. Chanrion, T. Neubert, J. Montanyà, F. Gangneron, Y. Meyerfeld, F. Lefeuvre, and G. Lointier (2010), Characteristics and conditions of production of transient luminous events observed over a maritime storm, J. Geophys. Res., 115, D16118, doi:10.1029/2009JD012066.

\section{Introduction}

[2] Several types of transient luminous events (TLEs) have been identified, and their physical features have been widely investigated. Sprites are streamers of short duration (0.01-0.1 s) and occur over mesoscale convective systems (MCSs) thanks to a quasi-static electric field resulting from a positive cloud-to-ground $(+\mathrm{CG})$ flash which generates a strong charge moment change (CMC) [Boccippio et al., 1995; Sentman et al., 1995; Lyons, 1996; Pasko et al., 1997; Neubert et al., 2001; Hayakawa et al., 2004; van der Velde et al., 2006; Asano et al., 2008]. They have been observed to consist of one or several columnar, carrotshaped, or variously shaped light emissions at altitudes of

\footnotetext{
${ }^{1}$ Laboratoire d'Aérologie, Université de Toulouse, CNRS, Toulouse, France.

${ }^{2}$ Electrical Engineering Department, Technological University of Catalonia, Terrassa, Spain.

${ }^{3}$ National Space Institute, Technical University of Denmark, Copenhagen, Denmark.

${ }^{4}$ Laboratoire Physique et Chimie de l'Environnement, Université d'Orléans, Orléans, France.
}

Copyright 2010 by the American Geophysical Union. 0148-0227/10/2009JD012066 between 40 and $90 \mathrm{~km}$. Halos are downward-descending diffuse glows from altitudes of about 80 to $65 \mathrm{~km}$. They can precede sprites after a $+\mathrm{CG}$ flash or follow a CG flash of either polarity [Miyasato et al., 2002, 2003; Bering et al., 2004]. They are red in color and smaller than elves, with a maximum diameter of $100 \mathrm{~km}$. Elves are red-colored donut-shaped light emissions at the base of the ionosphere $(\sim 90 \mathrm{~km})$, rapidly produced after a large-peak-current CG flash (>100-120 kA) [Boeck et al., 1995; Fukunishi et al., 1996; Huang et al., 1999; Frey et al., 2005]. They are very brief (hundreds of microseconds) and therefore difficult to detect with video systems [Barrington-Leigh et al., 2001].

[3] Chen et al. [2008] have shown the global distribution of the different TLEs observed from the Imager of Sprites and Upper Atmospheric Lightning (ISUAL) experiment on board the FORMOSAT-2 satellite. Analyzing 6737 TLEs observed from July 2004 to June 2007, they found that $80 \%$ of the events were elves, which occurred essentially over coastal or oceanic areas where the sea surface temperature exceeded $26^{\circ} \mathrm{C}$. The other TLEs were sprites and halos ( $10 \%$ each). Sprites were observed above regions with high-lightning activity, e.g., central Africa, the western Atlantic Ocean, southern America, and the Japanese Sea. 
Sprites have been observed to occur both in the summer [Lyons, 1996; Neubert et al., 2005] and in the winter [Takahashi et al., 2003; Hayakawa et al., 2004; Matsudo et al., 2009; Yair et al., 2009a]. Most +CG flashes producing sprites occur during periods of low lightning storm activity and exhibit strong CMCs [Boccippio et al., 1995; Huang et $a l ., 1999$ ] as well as high average peak currents [São Sabbas et al., 2003; Soula et al., 2009]. Biswas and Hobbs [1990] have reported that the $\mathrm{CG}$ flashes are more intense over the ocean than over the continent. Seity et al. [2001] have found larger-peak currents for both polarities from lightning flashes in offshore coastal storms. Using data from the North American Lightning Detection Network (NALDN), Orville et al. [2002] have shown a sharp transition from low- to high-median negative peak current along the coasts. They found a much less pronounced transition for the $+\mathrm{CG}$ flashes. Lyons et al. [1998] have observed that the high positive peak current values $(\geq 75 \mathrm{kA})$ corresponded to the areas where large MCSs often occur, but these could also be due to two classes of thunderstorms: supercells and nocturnal MCSs. According to Orville and Huffines [2001], the median peak currents vary throughout the year with the minimum and maximum in summer and winter, respectively, for both polarities, but especially for $+\mathrm{CG}$ flashes. According to Füllekrug et al. [2002], the very intense negative CG (-CG) flashes occur more often over oceans than continents. Another study focused on very powerful lightning flashes, with optical observations made from Vela satellites [Turman, 1977]. It revealed that among the few cases detected, $\sim 65 \%$ were located over coastal areas, $\sim 23 \%$ were located over oceans, and $\sim 12 \%$ were located over continents. Price et al. [2002] found both a high fraction of $+\mathrm{CG}$ flashes and unusually large-peak currents for $\mathrm{CG}$ flashes produced by storms over the Gulf Stream close to the American coast. As noted by Price et al., these $+\mathrm{CG}$ flashes could potentially generate sprites and elves.

[4] During the TLE observation campaign in 2007, one storm provided an interesting case study corresponding to several criteria for producing powerful $\mathrm{CG}$ flashes. It occurred over the Mediterranean Sea, in the south of France, on the night of 15-16 November, under the center of a coldupper-level low-pressure area. Furthermore, most of the TLEs (sprites, elves, and halos) detected over the storm were observed with two cameras, so it was possible to determine their positions by triangulation. We attempted to describe several characteristic features of these TLEs and several aspects of their associated lightning activity, especially their evolution during the lifetime of the storm and the location of the sprites compared to that of their parent lightning strokes. So, it is worthwhile to compare the types of TLE detected above the storm with space observations made by Chen et al. [2008] and with other ground observations made over winter storms in other parts of the world.

\section{Data}

[5] Data from the French meteorological radar network ARAMIS were used to describe the structure of the storms and they also gave the rainfall pattern. This network now consists of 24 Doppler radars ( $\mathrm{C}$ band and $\mathrm{S}$ band) which cover the entire area of mainland France [Parent-du-
Châtelet et al., 2003]. The area under study is monitored by two of the radars, one located in southeast France close to Nice and another on the island of Corsica, both in $\mathrm{S}$ band. They have a range of approximately $250 \mathrm{~km}$ and systematically produce data for processing plan position indicator (PPI)-type images of the reflectivity factor every $5 \mathrm{~min}$. Because of the low elevation of the radar beam in conventional mode, these images were from low altitudes in the cloud systems. The cloud-top temperatures were provided by the Meteosat satellite from European Organization for the Exploitation of Meteorological Satellites (EUMETSAT) based on radiometer data in the thermal infrared band (IR) at 10.5-12.5 $\mu \mathrm{m}$.

[6] A lightning detection network, European Cooperation for Lightning Detection (EUCLID), provided data enabling the identification of location, polarity, peak current value, number of strokes, and timing of CG flashes. The network includes 18 sensors on French territory run by Météorage and 11 sensors in the neighboring Spanish and Italian areas. All sensors use both magnetic direction finding (MDF) and time of arrival (TOA) techniques to determine the location of CG strokes [Cummins et al., 1998]. The detection efficiency is $\sim 90 \%$ inland and close to the coast, but it can be significantly less in the area considered in the present study. Consecutive strokes are considered to belong to the same CG flash event, provided they occur within $0.5 \mathrm{~s}$ and within $4 \mathrm{~km}$. Data from a second lightning detection network (LINET) operated by the University of Munich were used to complete the description of the $\mathrm{CG}$ activity. This system uses the MDF and TOA techniques in the very low frequency (VLF)/low frequency (LF) range [Betz et al., 2004] and covers the French territory by using a number of sensors distributed over the country. Observations of broadband extremely low frequency (ELF)/VLF activity are available from a receiver located at Nançay $\left(47.38^{\circ} \mathrm{N}, 2.19^{\circ} \mathrm{E}\right)$, near Orléans, France. The system uses a simple square air-core magnetic loop antenna of a couple of meters in size. The sensitivity allows the measurement of magnetic fields as low as several tens of femtotesla per root Hertz, in the frequency range of $\sim 30$ to $50 \mathrm{kHz}$. The analogous outputs of the two channels are sampled at $100 \mathrm{kHz}$, and the system uses Global Positioning System (GPS)-based timing. It has been shown that the detection efficiency of broadband ELF/VLF receivers is close to $100 \%$ for $\mathrm{CG}$ discharges [Wood and Inan, 2002]. The ELF/VLF measurements are therefore useful for the identification of the $\mathrm{CG}$ flashes possibly missed by the lightning detection networks.

[7] During this specific night of observations, one camera system was located at the Pic du Midi $\left(42.93^{\circ} \mathrm{N}, 0.14^{\circ} \mathrm{E}\right.$, $2877 \mathrm{~m}$ altitude) [Chanrion et al., 2007]. It included two low-light high-resolution charge-coupled device (CCD) cameras mounted on a pan-tilt unit remotely controlled by the Internet. One was equipped with a $16 \mathrm{~mm}$ f1.4 lens with a $31^{\circ}$ field of view (FOV) and the other with a $50 \mathrm{~mm} \mathrm{f} / 0.95$ lens with a $7.5^{\circ} \mathrm{FOV}$. The exposure time was $42 \mathrm{~ms}$. The system time was synchronized to GPS time through the Network Time Protocol (NTP) and accurate to within a hundredth of a microsecond. Events were detected and stored by automated trigger software to reduce the data volume. A second camera (Watec 902H) was used at the Centre de Recherches Atmosphériques (CRA) in southwestern France $\left(43.13^{\circ} \mathrm{N}, 0.37^{\circ} \mathrm{E}, 600 \mathrm{~m}\right.$ altitude). It had a $12 \mathrm{~mm} \mathrm{f} / 0.8$ lens 

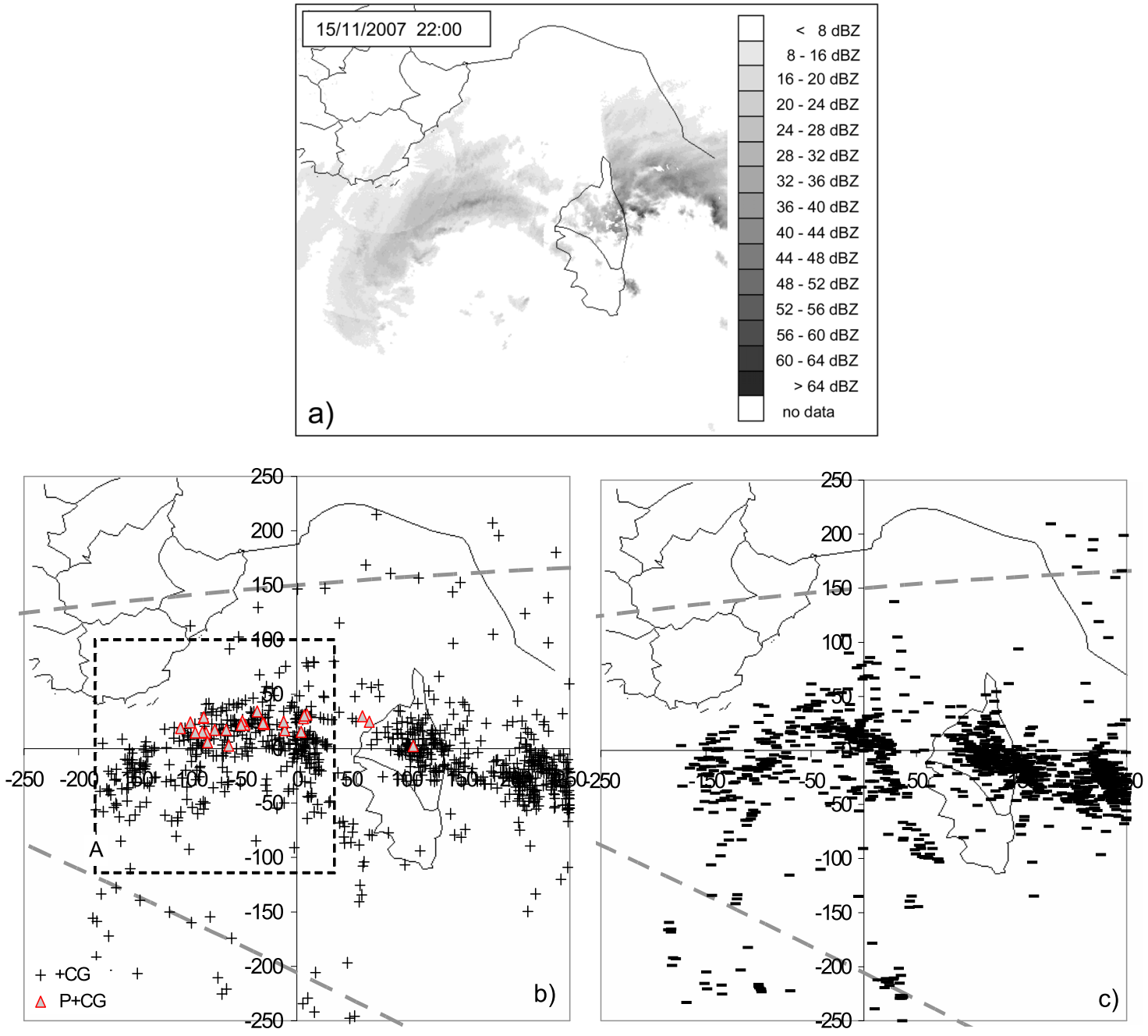

Figure 1. (a) Distribution of the radar reflectivity factor (plan position indicator) at $2200 \mathrm{UT}$ in a $500 \mathrm{~km} \times$ $500 \mathrm{~km}$ area in southeastern France (from $5^{\circ} \mathrm{E}$ to $11^{\circ} \mathrm{E}$ and from $40^{\circ} 15^{\prime} \mathrm{N}$ to $44^{\circ} 45^{\prime} \mathrm{N}$ ) on $15 / 16$ November 2007. The radar scale is in dBZ. (b and c) Location of the CG lightning flashes (pluses, positive; minuses, negative) detected by the European Cooperation for Lightning Detection network (EUCLID) in the same area, between 1500 UT on 15 November and 0500 UT on 16 November. The 26 "parent" flashes (all positive) are indicated with red triangles. A indicates the area for the study described in section 4, and the dotted lines draw the field of view $\left(31^{\circ}\right)$ of the camera at the Centre de Recherches Atmosphériques.

$\left(\mathrm{FOV}=31^{\circ}\right)$, and it was connected via a GPS time-inserter unit to a personal computer (PC) equipped with trigger software, so all systems were time-synchronized.

\section{Storm and TLE Description}

\subsection{Meteorological Situation, Radar, and Lightning}

[8] On 15 November 2007, a cold-upper-level lowpressure area over central Europe and the northern Mediterranean Sea, with temperatures of $-32^{\circ} \mathrm{C}$ at altitude $5.5 \mathrm{~km}$, created convectively available potential energy (CAPE) of around $200-600 \mathrm{~J} / \mathrm{kg}$ within the convergence zone associated with a surface low-pressure area $(1006 \mathrm{hPa})$ west of Corsica. Over France, the northerly flow brought temperatures below freezing, with snow occurring over eastern France during the day, while the temperatures over the sea were $11^{\circ} \mathrm{C}$ with dew points of $7^{\circ} \mathrm{C}$. The freezing level was located around $1000 \mathrm{~m}$. In Corsica, $200 \mathrm{~mm}$ of rainfall were recorded in $24 \mathrm{~h}$ in the southern parts of the island.

[9] Figure 1a displays a plan position indicator (PPI) of the radar reflectivity factor at 2200 UT during the active period of the storm, in a $500 \mathrm{~km} \times 500 \mathrm{~km}$ area. During several hours after 1900 UT, the system remained roughly stationary and exhibited almost no change in shape. The highest reflectivity values were located in northeast Corsica, with some values around 56 and $60 \mathrm{dBZ}$ at $2200 \mathrm{UT}$. In the $250 \mathrm{~km} \times 100 \mathrm{~km}$ crescent-shaped system located west of Corsica, the reflectivity factor was more uniform, with values rarely exceeding $40 \mathrm{dBZ}$. This system is comparable to an MCS because of the distribution and the values of the reflectivity factor and its size.

[10] Figure 1 also shows the location of the CG flashes detected by EUCLID in the same area, between 1700 UT on 15 November 2007 and 0500 UT on 16 November 2007, for 
Table 1. Transient Luminous Events Observed During the Whole Activity of the Convective System, the Number of Positive Parent Cloud-To-Ground Lightning Flashes Associated, and Their Peak Current Values ${ }^{\mathrm{a}}$

\begin{tabular}{lcccc}
\hline \multicolumn{1}{c}{ Category } & TLE & $\begin{array}{c}\text { Sprite } \\
\text { (Only Sprite) }\end{array}$ & $\begin{array}{c}\text { Halo } \\
\text { (With Sprite) }\end{array}$ & $\begin{array}{c}\text { Elve } \\
\text { (With Sprite) }\end{array}$ \\
\hline Number & 30 & $27(19)$ & $6(4)$ & $5(4)$ \\
Located P+CG & 26 & $24(16)$ & $5(4)$ & $5(4)$ \\
$\mathrm{I}_{\text {MAX }}(\mathrm{kA})$ & 384 & $384(125)$ & $312(312)$ & $384(384)$ \\
$\mathrm{I}_{\text {AVE }}(\mathrm{kA})$ & 147 & $146(63)$ & $259(272)$ & $304(351)$ \\
$\mathrm{I}_{\text {MIN }}(\mathrm{kA})$ & 29 & $29(29)$ & $204(238)$ & $118(288)$ \\
\hline
\end{tabular}

${ }^{\text {a}}$ Peak current values are maximum, average, and minimum. TLE, transient luminous event.

$+\mathrm{CG}$ (Figure 1b) and -CG (Figure 1c). Overall, $913+\mathrm{CG}$ flashes and $1374-\mathrm{CG}$ flashes were detected, which corresponds to a high proportion for $+\mathrm{CG}(40 \%)$. The average peak currents were 49 and $-30 \mathrm{kA}$ (median values 34 and $-20 \mathrm{kA}$ ), and the average multiplicities were 1.1 and 1.7 for $+\mathrm{CG}$ and $-\mathrm{CG}$, respectively. No filtering was applied in this case for low-peak current values, because very few were observed. Compared to a study of TLEs-bearing storms using data from the same detection system, the average peak positive currents were high. Soula et al. [2009] found peak current averages of around $33 \mathrm{kA}$ for $+\mathrm{CG}$ flashes (including sprite-parent $+\mathrm{CG}$ flashes) in two case studies over land in France. According to Orville and Huffines [2001], who made a long-term study of CG lightning activity in the United States, the CG peak currents were higher in the months from November to March, especially for the $+\mathrm{CG}$ flashes. Our case study is in accordance with these findings.

\subsection{TLEs}

[11] The cameras were operated at about 2215 UT, and a total of 30 TLEs were observed until 0500 UT. In Figure 1, the dashed lines indicate the FOV of the CRA camera $\left(31^{\circ}\right)$ when it roughly pointed toward the center of the storm system. As noted in Table 1, of these 30 events, 27 produced a sprite and, of these, 8 occurred in combination with another phenomenon which was either an elve (4) or a halo (4). A

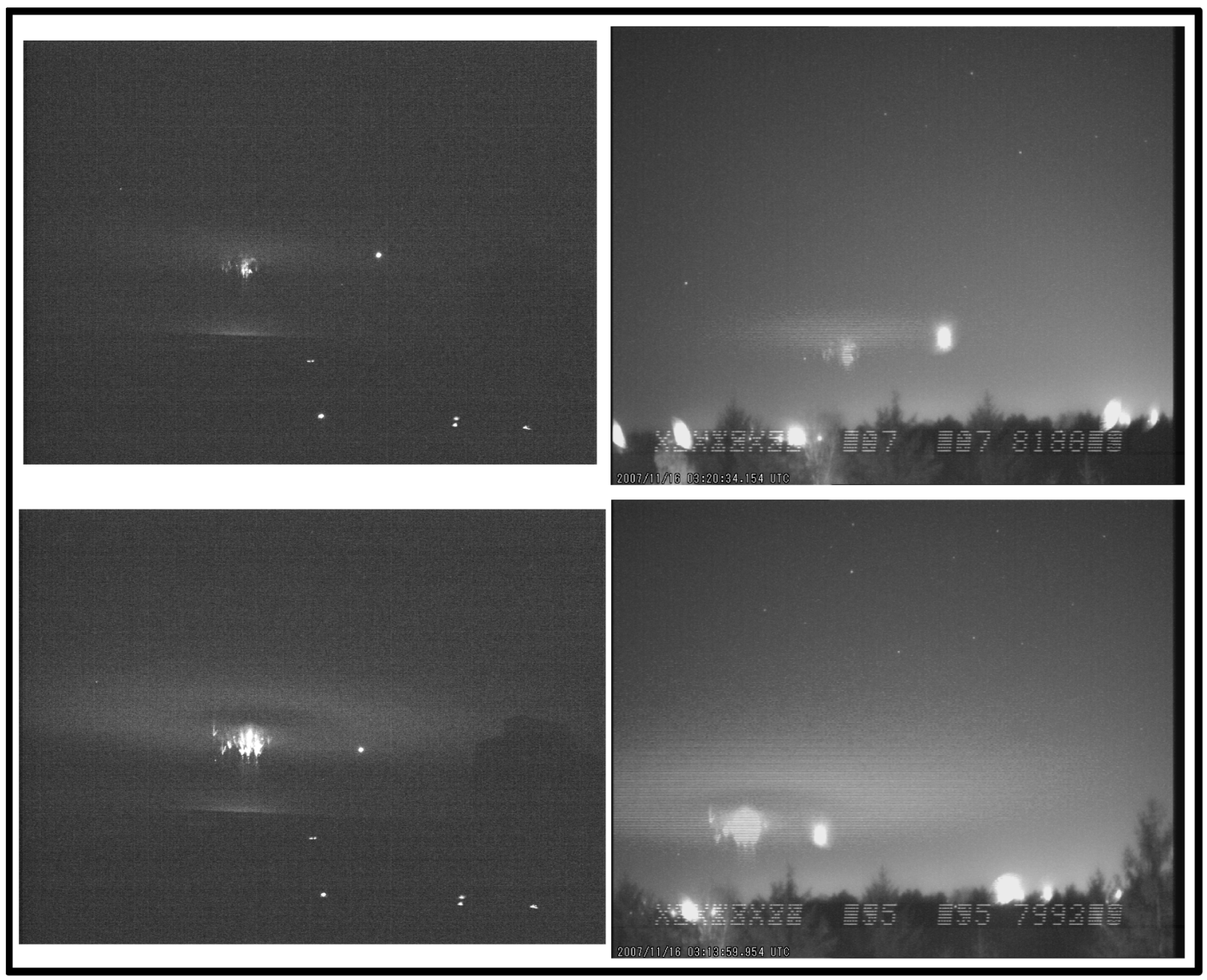

Figure 2. Two examples of transient luminous events (TLEs) observed during the night (left) with the camera at Pic du Midi and (right) with the camera at the Centre de Recherches Atmosphériques. (top) Sprite with halo at 320:34 UT; (bottom) sprite with elve at 0314 UT. 


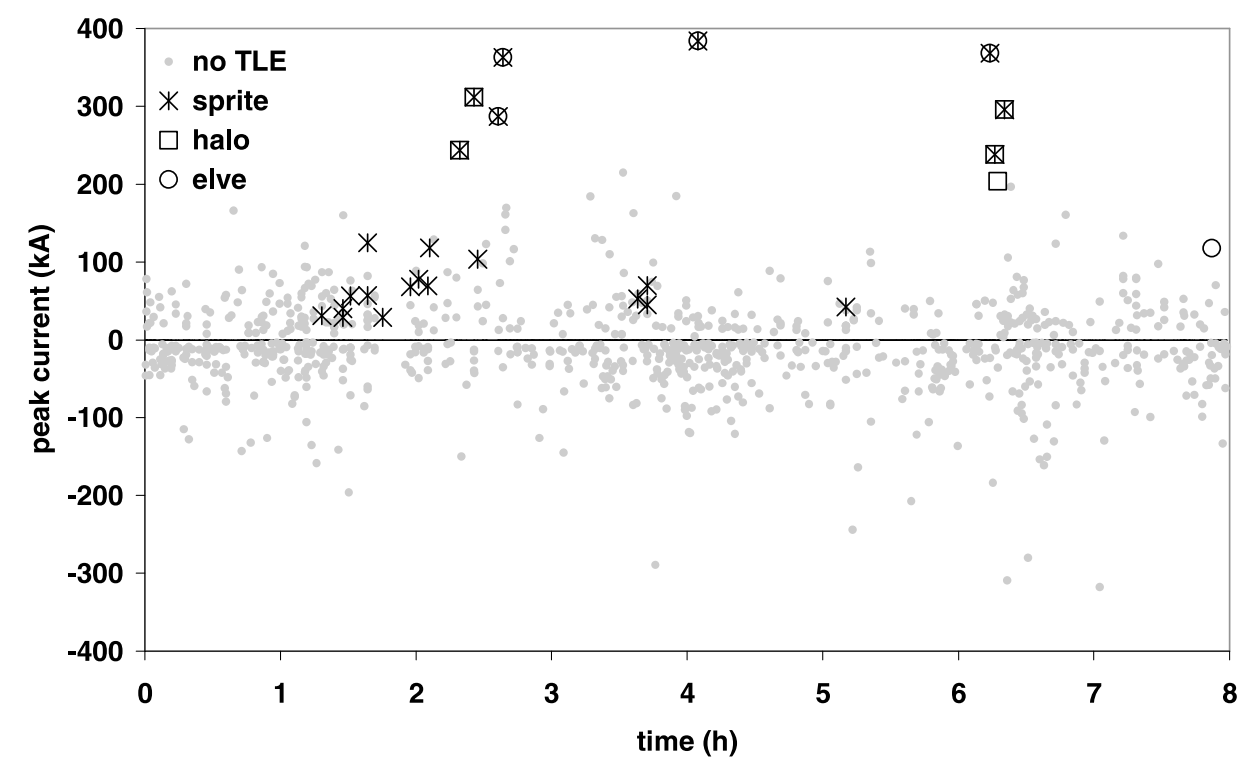

Figure 3. Time series of peak current for cloud-to-ground flashes detected with EUCLID and for all the positive parent cloud-to-ground lightning $(\mathrm{P}+\mathrm{CG})$ flashes detected with EUCLID and LINET $(\mathrm{t}=0$ corresponds to $2100 \mathrm{UT}$ ).

large proportion of the halos and elves observed were therefore associated with a sprite, four out of six and four out of five, respectively. Among the 19 sprites, 2 were detected in quick succession (less than $1 \mathrm{~s}$ ) after a previous sprite (less than $1 \mathrm{~s}$ ), and the rest were detected after a new P+CG flash. Figure 2 displays two examples of these TLE images observed from both cameras mentioned in section 2 . Figure 2 (left) is from the camera at Pic du Midi. Figure 2 (right) is from the CRA, and each pixel displays the maximum light emission recorded over the duration of the video. Figure 2 (top) is a sprite with a halo at 0320:34 UT, and Figure 2 (bottom) is an elve with a sprite at 0314:00 UT.

\subsection{TLE-Producing CG Flashes}

[12] Among the 30 TLEs, 26 were clearly associated with a $\mathrm{P}+\mathrm{CG}$ flash detected and located within the storm system. The $26 \mathrm{P}+\mathrm{CG}$ flashes are indicated in Figure $1 \mathrm{~b}$ with red triangles. The large majority of the $\mathrm{P}+\mathrm{CG}$ flashes were located in a relatively confined part of the system, the most stratiform area west of Corsica. Only three $\mathrm{P}+\mathrm{CG}$ flashes were located in the most convective cloud area over or east of Corsica. Figure 3 displays the time series of the peak currents of the CG flashes recorded by EUCLID (and LINET for some $\mathrm{P}+\mathrm{CG}$ flashes). The first outbreak generated the most TLEs and started at $2218 \mathrm{UT}(1.30 \mathrm{~h}$ on the time scale), ended at $2338 \mathrm{UT}(2.64 \mathrm{~h})$, and included $16 \mathrm{P}$ $+\mathrm{CG}$ flashes. During this first period, all TLEs included a sprite, and four included a halo or an elve: two of each. The peak currents of the $\mathrm{P}+\mathrm{CG}$ flashes producing halos or elves were much larger than those producing only sprites, so all $\mathrm{P}$ $+\mathrm{CG}$ flashes with a peak current larger than about $200 \mathrm{kA}$ seem to have produced detected halos or elves. On the other hand, no $-\mathrm{CG}$ flash seems to have produced an elve, even when their peak current exceeded $200 \mathrm{kA}$ in absolute value. There is, therefore, an apparent dissymmetry between the polarities for elve production. Table 1 displays the peak current values of the $\mathrm{P}+\mathrm{CG}$ flashes. The $\mathrm{P}+\mathrm{CG}$ flashes producing the sprites exhibited an average peak current of $63 \mathrm{kA}$ and a maximum peak current of $125 \mathrm{kA}$. Those producing the halos and elves exhibited extreme average peak currents of 272 and $351 \mathrm{kA}$, with maximum peak currents of 312 and $384 \mathrm{kA}$, respectively.

[13] The ELF/VLF data enabled us to determine the time lag (after the parent flash) for three cases of the four TLEs without any $\mathrm{P}+\mathrm{CG}$ flash located. Figure 4 displays an example of these data after 2259:42.250 UT, which corresponds to a sprite shaped like a group of columns detected between 2259:42.392 and 2259:42.412 UT (between 142 and $162 \mathrm{~ms}$ on the Figure 4 scale). The detection systems did not identify the CG stroke which clearly produced an ELF/VLF signature at 2259:42.404 UT (154 ms), characteristic of a CG stroke, and so the time lag for the sprite was between 0 and $8 \mathrm{~ms}$, as calculated by the time of its video image. Another stroke is well identified in the graph at 2259:42.533 UT (283 ms); this stroke was detected by the location system as positive with a peak current at $24 \mathrm{kA}$. The time lag between the $\mathrm{P}+\mathrm{CG}$ flash and the TLE was then calculated for 29 out of the 30 events by distinguishing 26 sprites, 6 halos, and 5 elves. The time of a TLE was estimated as that of the half-video field in which it was detected, and so its time lag was calculated with an accuracy of $\pm 10 \mathrm{~ms}$, since the duration of a video field for the camera at the CRA was $20 \mathrm{~ms}$. When the $\mathrm{P}+\mathrm{CG}$ flash was detected later than the half-video field, a negative time lag was found by this method, and it was reduced to 0 . Figure 5 displays this time lag versus time starting at 2100 UT for all TLEs. The maximum time lag was higher for sprites compared to other categories of TLEs and seems to decrease during the storm lifetime.

\section{Analysis of the Conditions of TLE Production}

\subsection{Storm Evolution and Lightning Activity}

[14] In order to analyze the CG lightning activity and the structure of the storm system producing the TLEs, we 

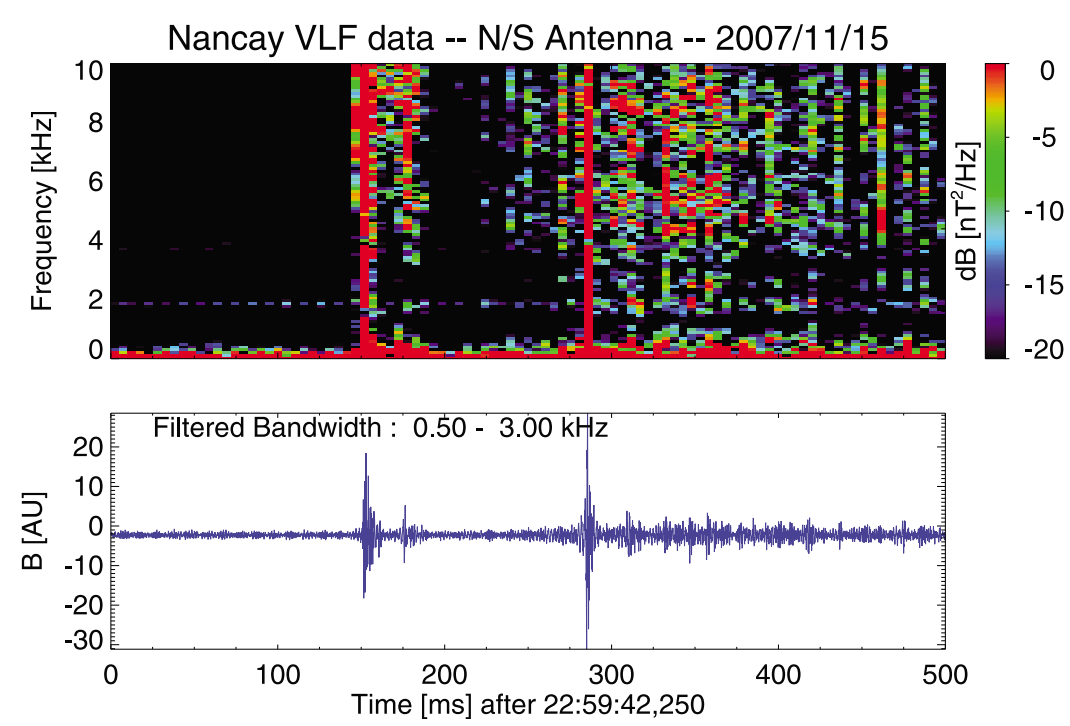

Figure 4. (top) Magnetic north-south component of ELF/VLF after 2259:42.250 UT wave spectra and (bottom) wave form filtered between 0.5 and $3.0 \mathrm{kHz}$. The bars indicate the $20 \mathrm{~ms}$ duration of the first video frame of the sprite.

selected the $\mathrm{CG}$ flashes detected in area $\mathrm{A}$, which is defined by the intervals $(-185 ;+35)$ and $(-115 ; 100)$ in Figure 1 . In total, $428+\mathrm{CG}$ and $397-\mathrm{CG}$ flashes were produced in area A between 1700 and 0500 UT. The proportion of $+\mathrm{CG}$ flashes was therefore larger than $50 \%$. The average peak current for these $+\mathrm{CG}$ and $-\mathrm{CG}$ flashes was 56 and $-26 \mathrm{kA}$ (38 and $-19 \mathrm{kA}$ for median values), respectively. The average multiplicity was 1.1 for $+\mathrm{CG}$ and 1.6 for $-\mathrm{CG}$. A difference can be noted in the peak current values by comparing them with CG flashes in the whole area of Figure 1 for the same period ( 49 and $-30 \mathrm{kA}$ ).

[15] Figure 6 displays the evolution of the storm system involved in the production of the CG flashes displayed in area A. Figure 6a displays the time series of the area of the cloud for several intervals of its top temperature, and Figure $6 \mathrm{~b}$ displays the time series of the precipitation mass integrated in areas with radar reflectivity included in different value intervals. The time series includes two periods of TLE production, one with 15 events and one with 4 events. The first period of TLE occurred during a decrease of the total cloud area, especially for that with cloud-top temperatures between $-40^{\circ} \mathrm{C}$ and $-25^{\circ} \mathrm{C}$, and during an increase of the area with tops colder than $-50^{\circ} \mathrm{C}$. At the same time, the precipitation mass produced by regions with radar reflectivity between 25 and $35 \mathrm{dBZ}$, i.e., by stratiform areas, increased. The two sprite periods followed the decline of the convective precipitation area, with reflectivity values larger than $35 \mathrm{dBZ}$. Similar results have been reported by

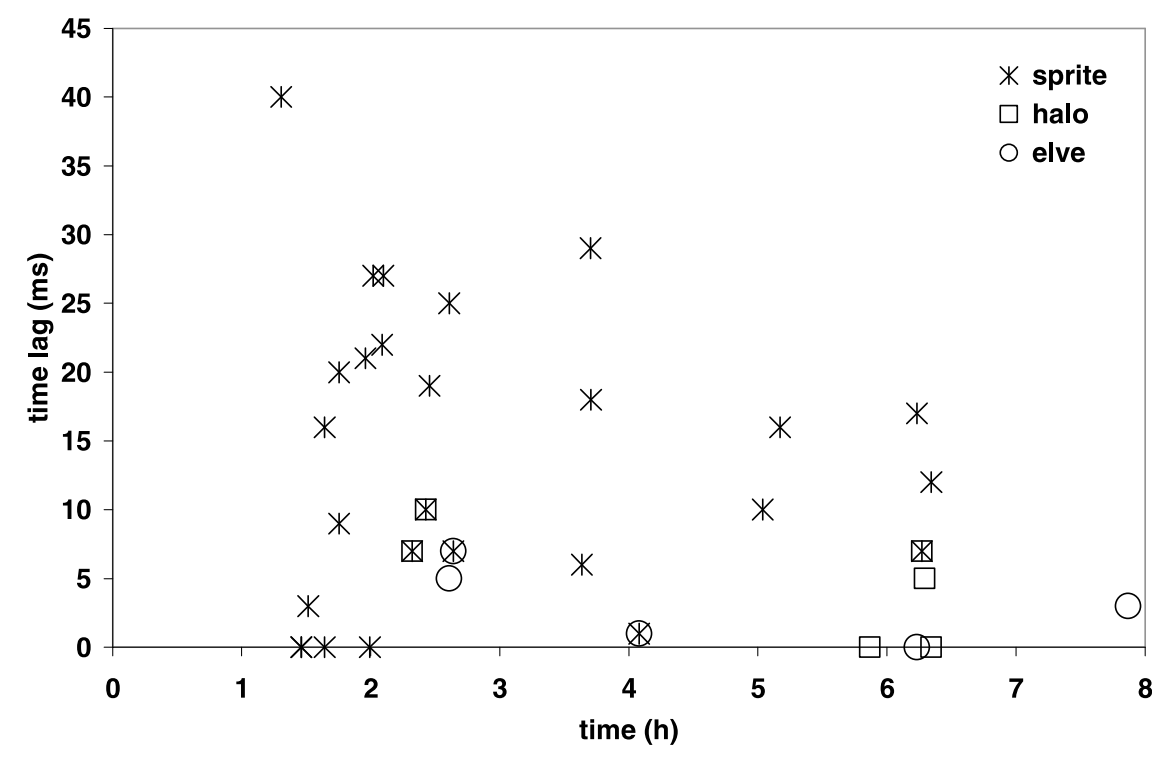

Figure 5. Time series of the time lag for 29 transient luminous events $(t=0$ corresponds to 2100 UT). 


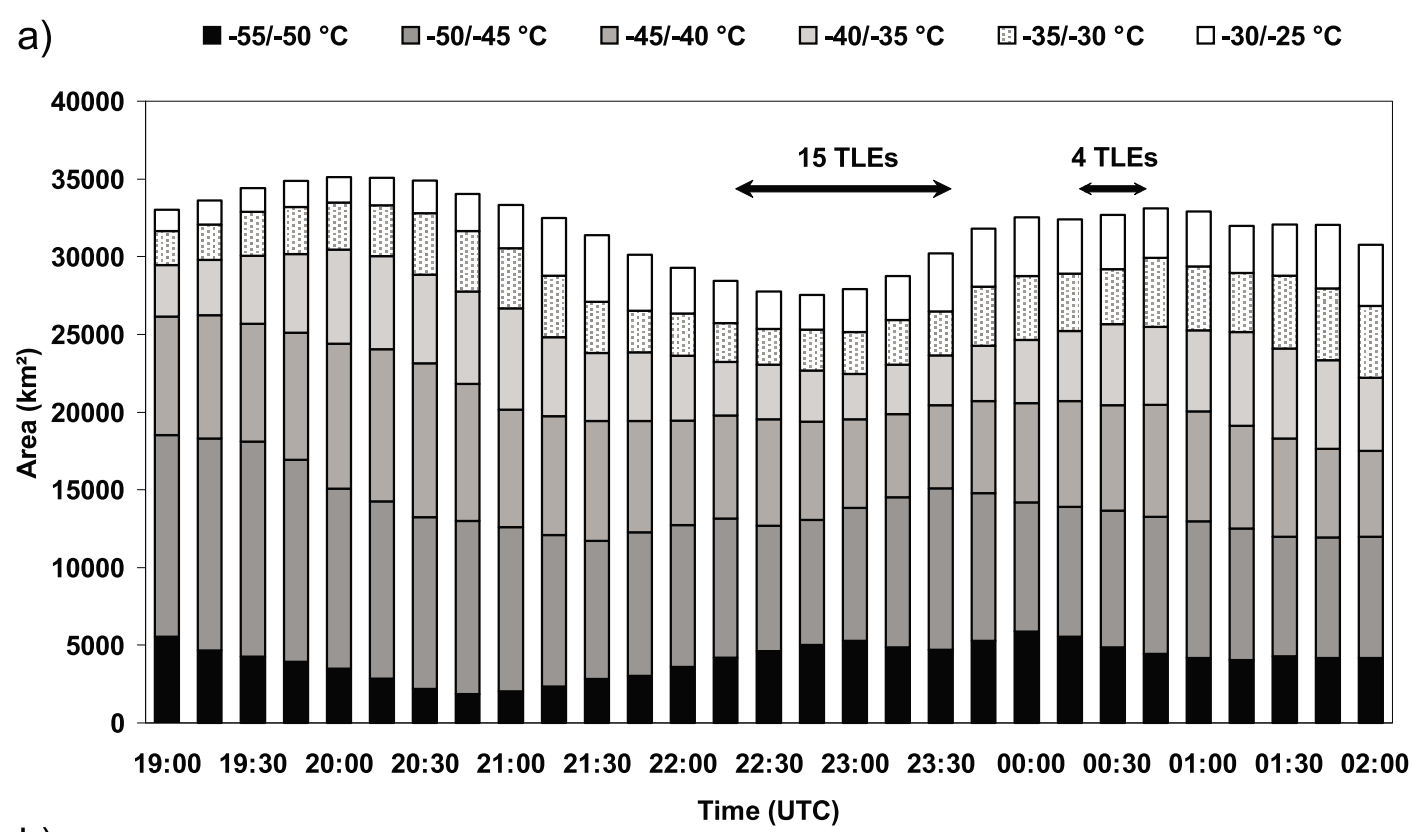

b)

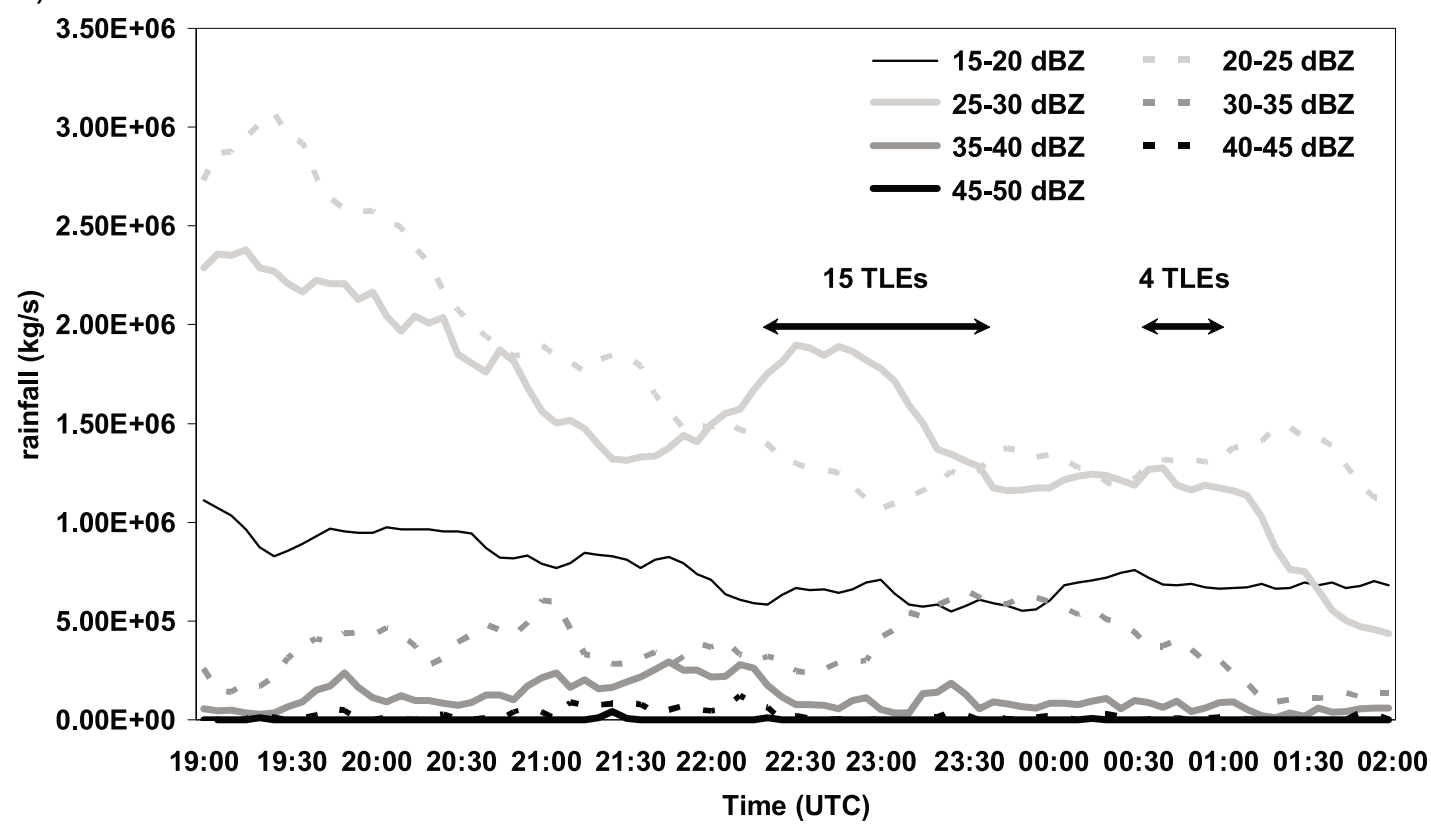

Figure 6. (a) Time series of the cloud area for several ranges of cloud-top temperatures between 1900 and 0200 UT for the convective system located west of Corsica in Figure 2. (b) Time series of the rainfall mass integrated over areas with radar reflectivity values included in $5 \mathrm{dBZ}$ wide intervals for the same period (TLE, transient luminous event).

Hayakawa et al. [2005] by considering the fractal analysis of two storms producing TLEs.

[16] The first period of TLE started at $2218 \mathrm{UT}$ and ended at $2338 \mathrm{UT}$, with 15 TLEs produced over the system located west of Corsica. The locations of the CG flashes corresponding to this period are displayed in Figure 7a: $35-\mathrm{CG}$ and $60+\mathrm{CG}$ flashes are superimposed on the radar reflectivity distribution at $2300 \mathrm{UT}$, approximately in the middle of the period. The $+\mathrm{CG}$ flashes were therefore largely dominant in this TLE period. The average peak currents were $-26 \mathrm{kA}$ for $-\mathrm{CG}$ and $68 \mathrm{kA}$ for $+\mathrm{CG}$. For $+\mathrm{CG}$ flashes, peak currents were therefore larger than during the whole period in area $\mathrm{A}$. The maximum value of radar reflectivity in the system at that time was between 36 and $40 \mathrm{dBZ}$. The $-\mathrm{CG}$ and $+\mathrm{CG}$ flashes spread out over specific areas; that is, the $-\mathrm{CG}$ roughly located at the edges and the $+\mathrm{CG}$ located in the main and central part of the crescent-shaped system. In order to show the evolution of this spatial distribution, the previous $1 \mathrm{~h}$ period (2118-2218 UT) has been presented in Figure $7 \mathrm{~b}$. The locations of the $\mathrm{CG}$ flashes were slightly different during this period. Both $\mathrm{CG}$ polarities were more mixed in the main part of the system and the upper edge was 

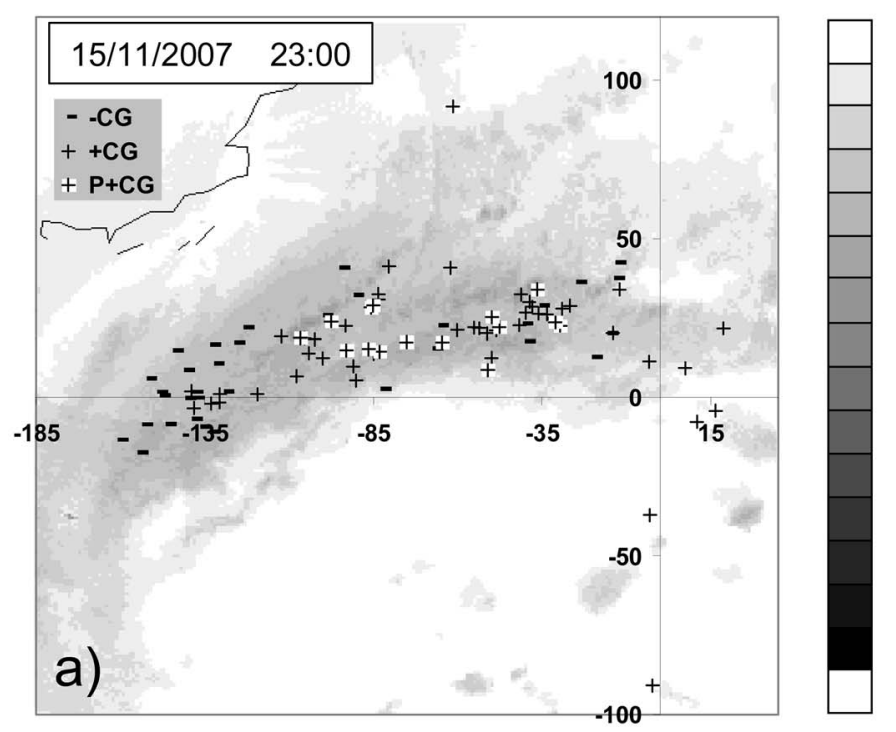

$<8 d B Z$
$8-16 d B Z$
$16-20 d B Z$
$20-24 d B Z$
$24-28 d B Z$
$28-32 d B Z$
$32-36 d B Z$
$36-40 d B Z$
$40-44 d B Z$
$44-48 d B Z$
$48-52 d B Z$
$52-56 d B Z$
$56-60 d B Z$
$60-64 d B Z$
$>64 d B Z$
no data
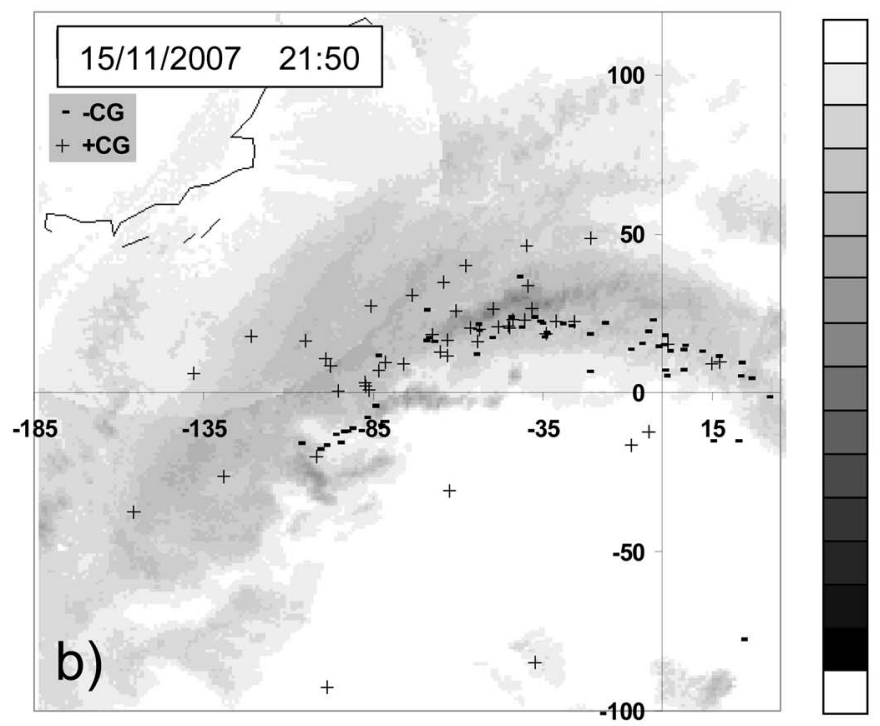

$<8 d B Z$
$8-16 d B Z$
$16-20 d B Z$
$20-24 d B Z$
$24-28 d B Z$
$28-32 d B Z$
$32-36 d B Z$
$36-40 d B Z$
$40-44 d B Z$
$44-48 d B Z$
$48-52 d B Z$
$52-56 d B Z$
$56-60 d B Z$
$60-64 d B Z$
$>64 d B Z$
no data

Figure 7. Radar reflectivity distribution in the cloud system west of Corsica (Area A) at 2300 UT with location of cloud-to-ground (CG) flashes (a) produced between 2218 and 2338 UT and (b) at 2150 UT, with the location of CG flashes produced between 2118 and 2218 UT. The axes are graduated in kilometers; area $\mathrm{A}$ is from $41^{\circ} 35^{\prime} \mathrm{N}$ to $43^{\circ} 35^{\prime} \mathrm{N}$ and from $5^{\circ} 48^{\prime} \mathrm{E}$ to $8^{\circ} 28^{\prime} \mathrm{E}$, centered at $7^{\circ} 8^{\prime} 32^{\prime \prime} \mathrm{E}$ and $42^{\circ} 35^{\prime} 24^{\prime \prime} \mathrm{N}$.

more prone to $+\mathrm{CG}$ flashes. Comparing the two distributions, the uniformly charged zone was larger during the TLE-producing period.

\subsection{Flash Sequences}

[17] For the analysis of $\mathrm{CG}$ flash production in area A, the time interval $\mathrm{dt}$ between a CG flash and the following one $(+\mathrm{CG}$ or $-\mathrm{CG})$ was calculated for $824 \mathrm{CG}$ flashes detected between 1700 and 0500 UT. Figure 8a displays the time series of this interval $\mathrm{dt}$, distinguishing between $-\mathrm{CG},+\mathrm{CG}$, and $\mathrm{P}+\mathrm{CG}$ flashes. From this graph, we can observe that there are two groups of CG flashes in terms of dt values. The first group includes low values $(\sim<2 \mathrm{~s})$ and the second group includes large values $(\sim 2 \mathrm{~s})$. The great majority of $\mathrm{P}+\mathrm{CG}$ flashes $(78 \%)$ belong to the group of low dt values. Con- sidering the whole duration, dt was lower than $2 \mathrm{~s}$ for $50 \%$ of the $-\mathrm{CG}$ flashes and was lower than $2 \mathrm{~s}$ for $65 \%$ of the $+\mathrm{CG}$ flashes. This signifies that compared to a $-\mathrm{CG}$ flash, a + CG flash was more often rapidly followed by another CG flash. This graph shows a new facet of the rhythm of CG flash production by a storm. For a thorough analysis, the time interval with the following CG flash $\mathrm{dt}_{\mathrm{after}}$ and that with the previous one $\mathrm{dt}_{\text {before }}$, are now considered for each $\mathrm{CG}$ flash. Figure $8 \mathrm{~b}$ displays the distribution of $\mathrm{dt}_{\mathrm{after}}$ versus $\mathrm{dt}_{\text {before }}$ for $823 \mathrm{CG}$ flashes produced in area A. Four groups of CG flashes clearly appear in the distribution. These groups correspond to the possible combinations between low $(<2 \mathrm{~s})$ and large $(>2 \mathrm{~s})$ values of both time intervals. Now, it is interesting to compare the characteristics of the CG flashes constituting each group. Figure $8 \mathrm{c}$ shows the 
a)
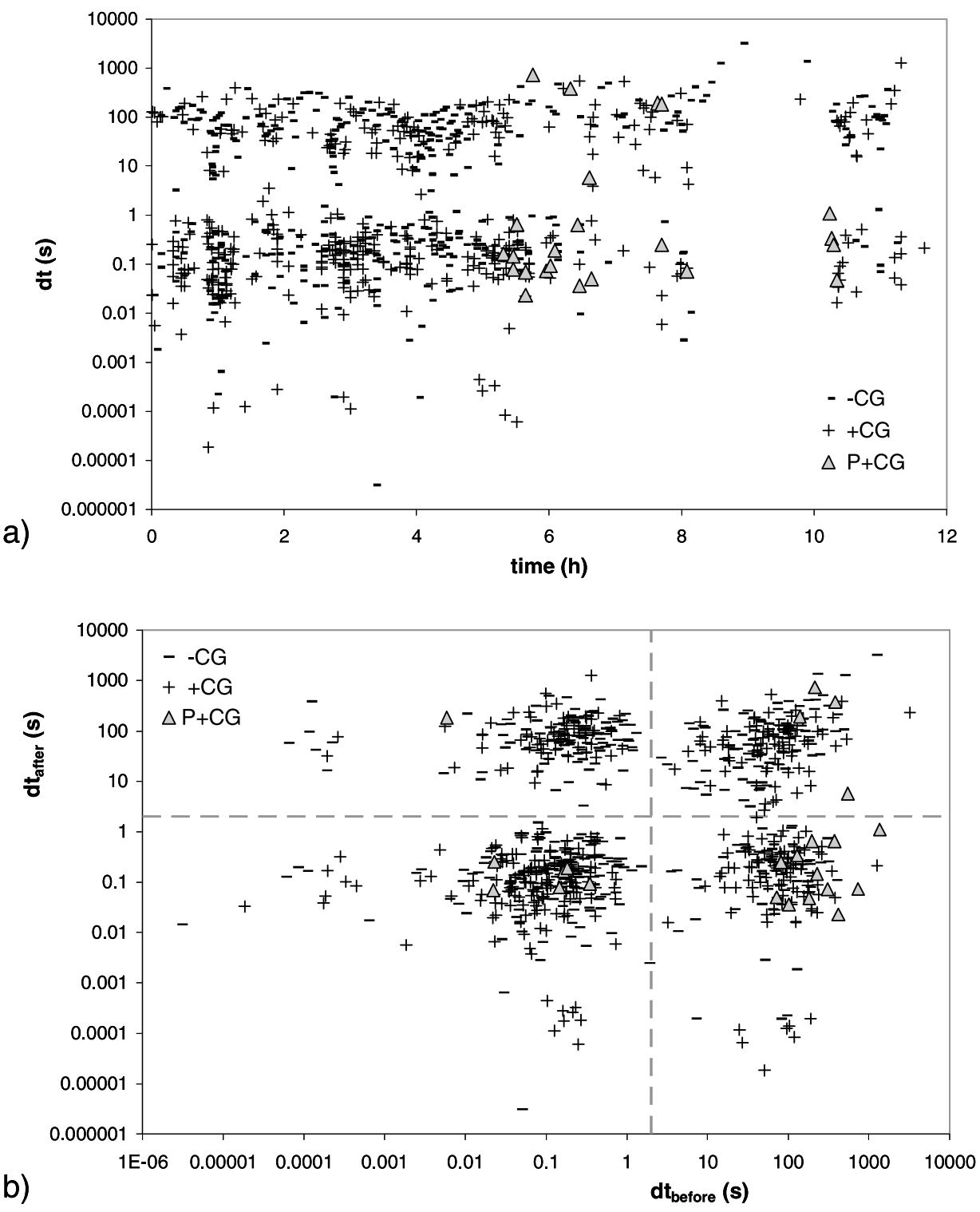

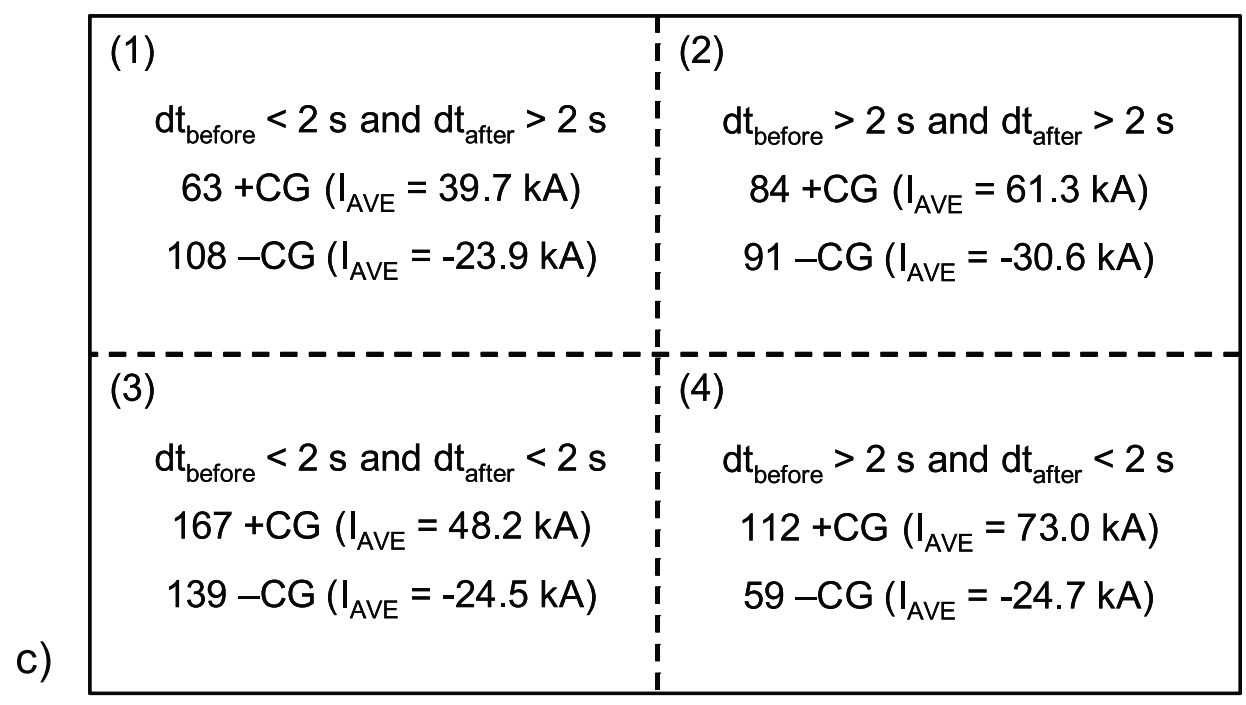

Figure 8 


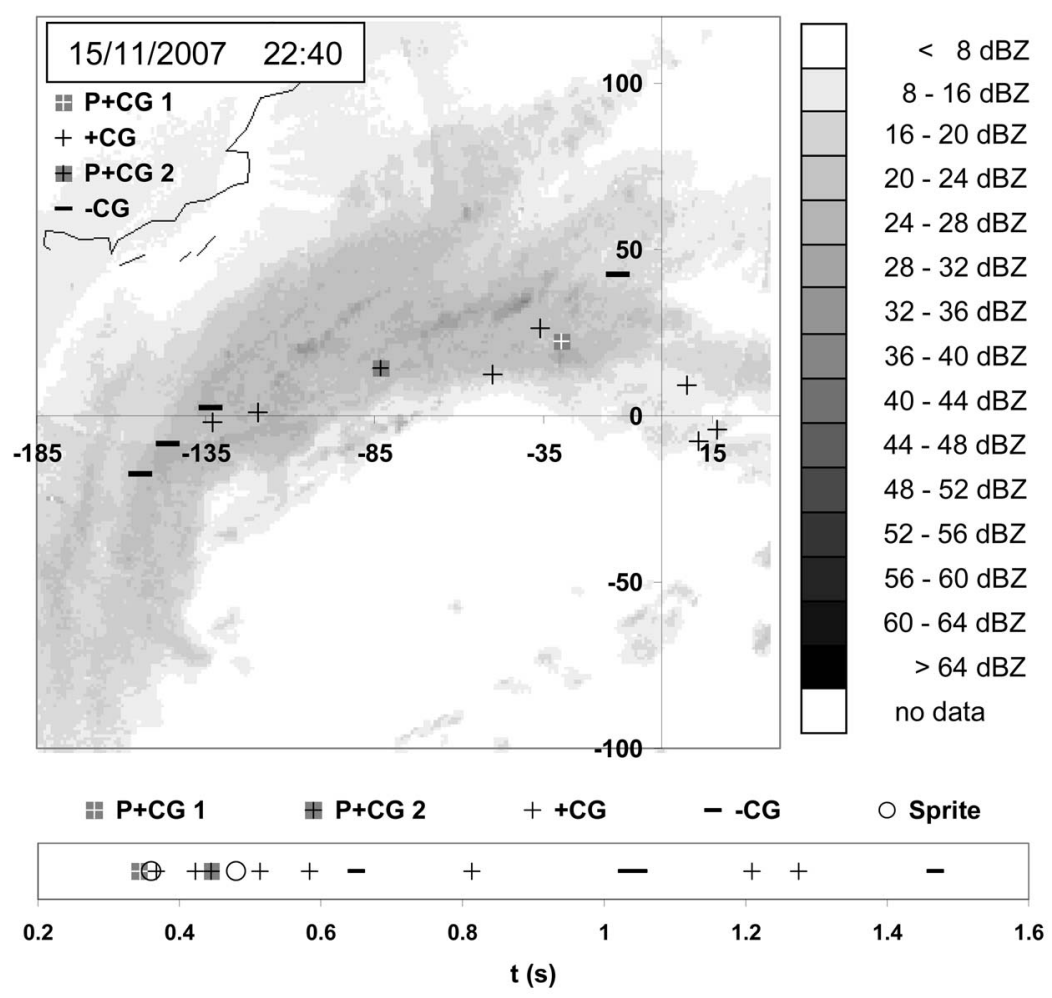

Figure 9. (top) Radar reflectivity distribution in the cloud system west of Corsica at 2240 UT, with the location of cloud-to-ground (CG) flashes associated with two sprites at 2238:38 UT. (bottom) Time series of the events (CG flashes and sprites) after $2238: 38 \mathrm{UT}(\mathrm{t}=0)$. Area is from $41^{\circ} 35^{\prime} \mathrm{N}$ to $43^{\circ} 35^{\prime} \mathrm{N}$ and from $5^{\circ} 48^{\prime} \mathrm{E}$ to $8^{\circ} 28^{\prime} \mathrm{E}$, centered at $7^{\circ} 8^{\prime} 32^{\prime \prime} \mathrm{E}$ and $42^{\circ} 35^{\prime} 24^{\prime \prime} \mathrm{N}$.

number and the average peak current of the CG flashes of each polarity in the four groups. Domain 4 in Figure 8c, corresponding to large values of $\mathrm{dt}_{\text {before }}$ and low values of $\mathrm{dt}_{\mathrm{after}}$, includes the $\mathrm{CG}$ flashes which start a sequence of CG flashes (i.e., at least two CG flashes). Domain 3 (low values of both intervals) includes the CG flashes which are within a sequence. Domain 2 (large values of both intervals) includes isolated CG flashes. Domain 1 (large values of $\mathrm{dt}_{\mathrm{after}}$ and low values of $\left.\mathrm{dt}_{\text {before }}\right)$ includes $\mathrm{CG}$ flashes ending a sequence. Domain 4 contains a large majority of $+\mathrm{CG}$ flashes $(65.5 \%)$ which exhibit a very strong average peak current of $73 \mathrm{kA}$. Most $+\mathrm{CG}$ flashes were found in the sequences (domains 3 and 4 ), but the endings of sequences (domain 1) contain more $-\mathrm{CG}$ flashes $(63.2 \%)$. Domain 2 , in correlation with isolated $\mathrm{CG}$ flashes, contains almost equal proportions of $+\mathrm{CG}$ and $-\mathrm{CG}$ flashes. The average peak current of $-\mathrm{CG}$ flashes does not change significantly from one domain to another, while it can vary for $+\mathrm{CG}$ flashes: from $40 \mathrm{kA}$ in domain 1 to $73 \mathrm{kA}$ in domain 4 . The lowest values of the average peak current are in domain 1 (last $\mathrm{CG}$ flashes of a sequence) for both polarities.
[18] The sequences previously discussed sometimes exhibited large numbers of $\mathrm{CG}$ flashes. For example, the sequence at 2238:38 UT contained $13 \mathrm{CG}$ flashes, with two sprites observed. Figure 9 displays the location of the $13 \mathrm{CG}$ flashes, superimposed on the radar reflectivity, and the time series of the events: two sprites, two $\mathrm{P}+\mathrm{CG}$ flashes, seven $+\mathrm{CG}$ flashes, and four $-\mathrm{CG}$ flashes. The first $\mathrm{P}+\mathrm{CG}$ flash had a peak current of $125 \mathrm{kA}$ and triggered a sprite. Two other $+\mathrm{CG}$ flashes occurred after this one and preceded a new $\mathrm{P}+\mathrm{CG}$ flash with a peak current of $57 \mathrm{kA}$ and two other $+\mathrm{CG}$ flashes. These six $+\mathrm{CG}$ flashes, produced within $240 \mathrm{~ms}$, were found increasingly westward, the first being nearly $100 \mathrm{~km}$ from the last. Assuming that these flashes were all physically connected, the distance and the time interval which separated the $+\mathrm{CG}$ flashes lead to a velocity of $4 \times 10^{5} \mathrm{~m} \mathrm{~s}^{-1}$ (i.e., in the range of that of a negative leader propagation [Mazur et al., 1998]). Such propagation could be interpreted as a spider-type lightning process, but no information about VHF radiation, typically associated with negative leaders, was available. The $-\mathrm{CG}$ flashes were located, more or less, in the extreme parts of the cloud area. The CG flashes of the sequence spread out through the whole

Figure 8. (a) Distribution of the time interval between two consecutive cloud-to-ground (CG) flashes (positive or negative) versus time between $1700 \mathrm{UT}(\mathrm{t}=0)$ and $0500 \mathrm{UT}(\mathrm{t}=12)$ in area A. (b) Distribution of the time interval dt $\mathrm{t}_{\text {after }}$ versus $\mathrm{dt}_{\mathrm{before}}$ for the same negative $\mathrm{CG}(-\mathrm{CG})$ and positive $\mathrm{CG}(+\mathrm{CG})$ flashes. The parent flashes are indicated with triangles. (c) Characteristics of the $\mathrm{CG}$ flashes for the four domains according to the values of $\mathrm{dt}_{\text {after }}$ and $\mathrm{dt}_{\text {before }}$ : number and average peak current $\mathrm{I}_{\mathrm{AVE}}$ for the $-\mathrm{CG}$ and $+\mathrm{CG}$ flashes. 


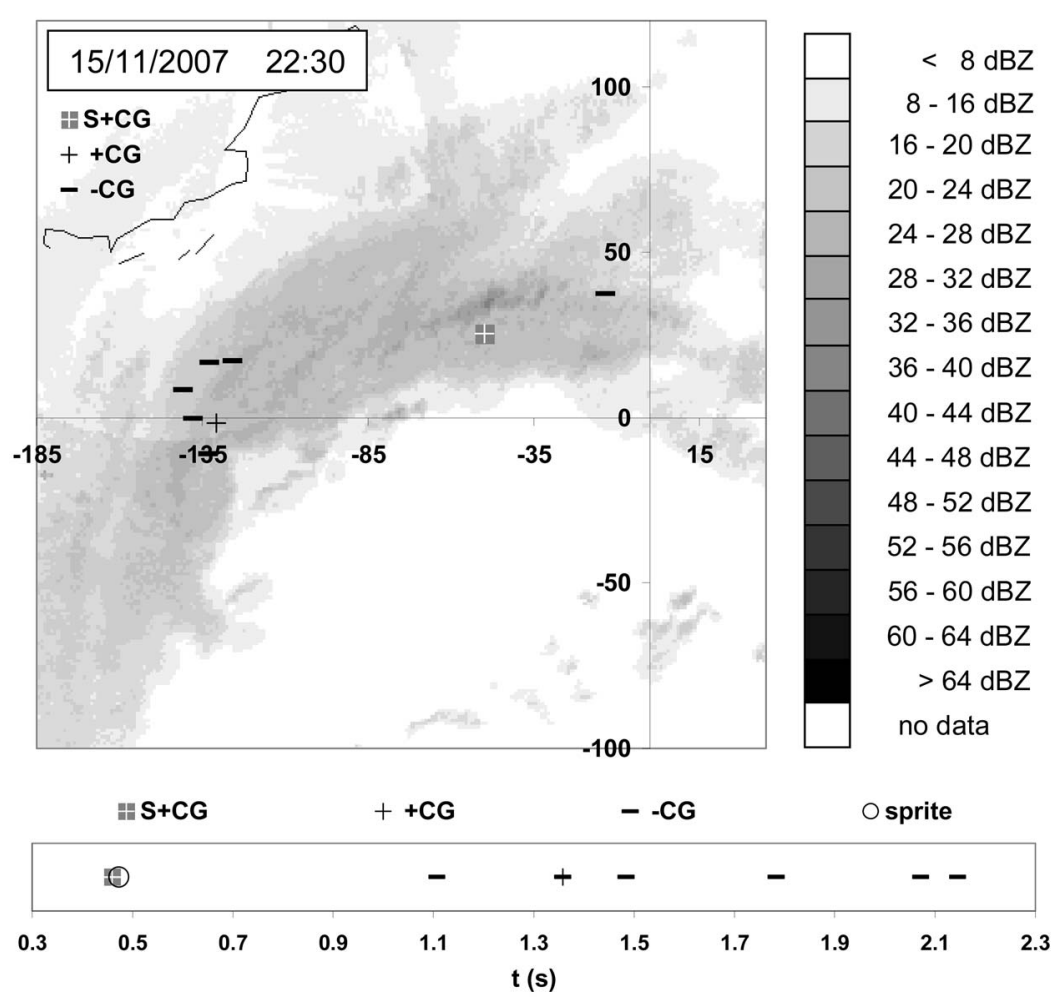

Figure 10. Same as Figure 9 but for the sprite at 2230:57 UT.

area affected by lightning. A second case of such a sequence is plotted in Figure 10 and corresponds to a sprite event at 2230:57 UT. During this sequence, which lasted for about $2 \mathrm{~s}$, one $\mathrm{P}+\mathrm{CG}$ flash occurred close to the largest reflectivity values preceding the sprite by a lag of between 13 and $33 \mathrm{~ms}$. The peak current of this $\mathrm{P}+\mathrm{CG}$ flash was $56 \mathrm{kA}$. Another $+\mathrm{CG}$ flash was produced $900 \mathrm{~ms}$ later, at a distance of $85 \mathrm{~km}$. From the distance and the time interval between the two $+\mathrm{CG}$ flashes, the velocity of an assumed propagation process (in-cloud leader) between them is estimated to be in the range of $10^{5} \mathrm{~m} \mathrm{~s}^{-1}$ in this case too. The other CG flashes within the sequence were negative and located near the edges of the area.

\subsection{Sprite Location}

[19] A total of 23 TLEs were recorded by two cameras during the night of observations (22 associated with a located $\mathrm{P}+\mathrm{CG}$ flash). The images from each camera were used as background in the software SkyCharts (freely obtained under the GNU Public License at http://www.stargazing.net/ astropc/, version 2.76), and the stars were fitted by adjusting the direction and the field of view. The accuracy of the azimuths for an event depends on the focal length of the lens and the resolution of the camera. A sprite is usually much wider than the readout of the azimuth, which varies typically only within 10 arc minutes. The resulting error of a great circle path at a $300 \mathrm{~km}$ distance is less than $1 \mathrm{~km}$. However, in this study, the conditions of triangulation were not very good, since the two cameras were only separated by $28 \mathrm{~km}$ in a perpendicular direction compared to the event directions, and so the angle of triangulation from the two cameras for an event at a distance of about $600 \mathrm{~km}$ was only $2.6^{\circ}$, and the error on the distance of the intersection was several tens of kilometers. However, the resulting positions were not randomly distributed around the $\mathrm{P}+\mathrm{CGs}$ but were offset to one side.

[20] Sprite location above the storm was determined for all cases of sprites where triangulation was possible. Figure 11 displays the set of these determinations for 14 sprites generated during the first period of TLE production. The $\mathrm{P}+\mathrm{CG}$ flash locations are indicated in each case. The sprite location is displayed for several elements, when it covered a large area (generally the elements corresponding to the edges of the sprite). The correspondence of the sprite to the $\mathrm{P}+\mathrm{CG}$ flash is indicated by a line. The dotted lines indicate sprites produced in the eastern part of the area in order to make the graph clearer. The group of events located in the western part of the area (nine cases) roughly exhibits the same orientation (i.e., the sprites were always 10 to $50 \mathrm{~km}$ to the west of their $\mathrm{P}+\mathrm{CG}$ flash). Sprites located in the eastern part (five cases) moved in different directions. The sprites were rarely located above the $\mathrm{P}+\mathrm{CG}$ flash strokes. The size of the largest sprites scaled well with that of the stratiform area, and the smaller ones were very close to its center (in the y direction). Some sprites were located over the edges of the stratiform area of the cloud, probably discharged by the $\mathrm{P}+\mathrm{CG}$ flash, as shown by Stanley et al. [2007], using TLE video observations and lightning mapping data.

\section{Discussion and Conclusion}

[21] A storm located over the Corsican region of the Mediterranean, producing 30 TLEs observed from southwestern France during the night of 15 and 16 November 


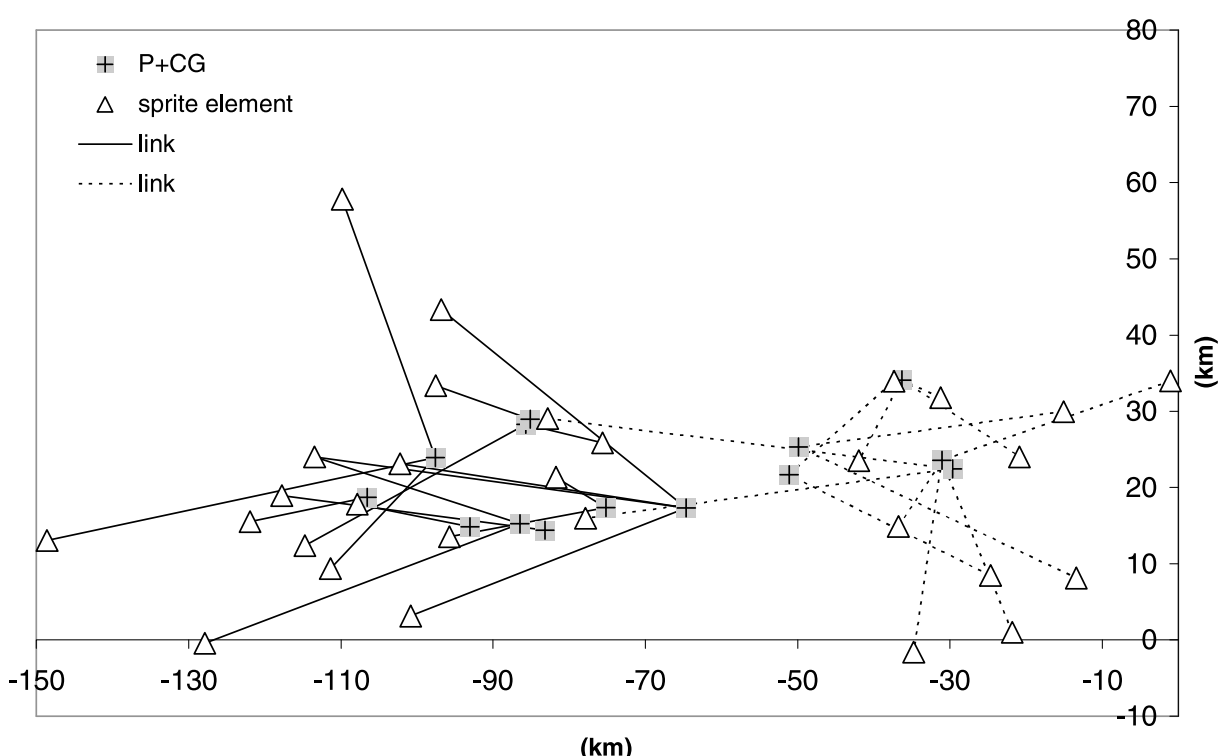

Figure 11. Location of some elements of the 14 sprite events and of their positive parent cloud-toground lightning $(\mathrm{P}+\mathrm{CG})$ flashes in the cloud system located west of Corsica.

2007 has been analyzed. It had many of the characteristics of a winter thunderstorm. The freezing level was only at about one third of the height of typical summer values. The cloud-top temperature of the main area reached between $-45^{\circ} \mathrm{C}$ and $-50^{\circ} \mathrm{C}$ during the period of TLE production, which according to the soundings, corresponded to a cloudtop altitude of about $7.2 \mathrm{~km}$. This is about half the cloud-top height typically observed for summer MCSs, and it is similar to the cloud tops observed by Yair et al. [2009a] (5-9 km for winter cells producing the TLEs) or by Pineda et al. [2008] for a winter storm producing sprites and elves in the region of Barcelona during the same campaign (5.5-7.3 km above the P+CG strokes, approximately). Takahashi et al. [2003] found lower values for the top cloud altitude in regard to their TLE-producing winter storms, and they also observed a larger proportion of elves. Soula et al. [2009] showed sprites were produced during periods with an increased area of cloud, exhibiting moderate radar reflectivity values in two summer storms. The same observation was made in the present case but with lower values of reflectivity. According to Myokei et al. [2009], winter storms in Japan tend to produce more columns when their vertical development is lower. In the present case, the sprites were difficult to classify because of the distance; however, both column and carrot types occurred.

[22] Among the 30 TLEs, five included an elve and six included a halo. This proportion of elves and haloes is high compared to previous observations made in European campaigns [Neubert et al., 2001, 2005; Soula et al., 2009]. The particularities of the storm conditions are their location and their season: past storms were over land and during summer, whereas the storm analyzed here was over the sea during the fall. Our observations confirm the conclusions of Chen et al. [2008] that most elves are produced over oceans or near the coastline in specific regions. The ratio of elves to sprites (5 to 27) in the present case corresponds to the observations reported by Yair et al. [2009a] of storms off the coast of Israel (10 to 56). On the other hand, Yair et al. did not mention events with both types observed simultaneously. In the present case, most elves (four out of five) and halos (four out of six) were followed by a sprite.

[23] We observed an apparent dissymmetry in the polarity of the CG flashes producing elves and halos: unexpectedly, all were produced by positive flashes, which is different from previous findings made by other authors (Bering et al. [2004] and Barrington-Leigh et al. [2001] for halos; Fukunishi et al. [1996] for elves). No elve and no halo (bright enough to be detected) were observed in association with large negative peak current $-\mathrm{CG}$ flashes. Since most were observed preceding, or simultaneously with, sprites, one may be inclined to believe the elves and the halos were detected because of the accompanying sprites. However, the detection software indicated, for example, that all elves consisted of many pixels exceeding the triggering threshold and, for two out of four cases, the triggering frame contained an elve without a sprite. As shown, for example, by Inan et al. [1997], Huang et al. [1999], and Hobara et al. [2001], the peak current is the essential parameter for triggering an elve. According to numerical simulation studies [Rakov and Tuni, 2003], the strong electromagnetic pulse (EMP) produced by a large peak current can initiate an elve, and so the - CG elves may have been much less bright, or absent. Asano et al. [2009] and Montanyà et al. [2010] have shown that halos are triggered earlier than sprites. For halos, the luminosity and the time lag calculated are weaker and longer, respectively, when the rise time of the return stroke is lower. This result indicates the long-lag halos may not be luminous enough to be detected by the cameras. According to recent studies, sprites could be initiated rapidly after the return stroke (typically 1.5 to $\sim 2 \mathrm{~ms}$ ) if its $\mathrm{CMC}$ is large enough, but they can be produced with longer lags, thanks to fast varying current surges ( $\mathrm{M}$ components) after the return stroke [Yashunin et al., 2007; Asano et al., 2009]. Recently, Matsudo et al. [2009] found large average values of lags for sprites in Japanese winter storms, especially over the Hokuriku area $(90 \mathrm{~ms})$, while over the Pacific Ocean, 
they found about $43 \mathrm{~ms}$. The $\mathrm{P}+\mathrm{CG}$ flashes producing the sprites exhibited an average peak current of $63 \mathrm{kA}$, a value close to those found in other studies [Fukunishi et al., 1996; São Sabbas et al., 2003; Pinto et al., 2004; Soula et al., 2009].

[24] The analysis of the time intervals between two consecutive $\mathrm{CG}$ lightning flashes in the main area producing the TLEs led to a classification of the CG flashes within different groups. For each type $(-\mathrm{CG},+\mathrm{CG}$, and $\mathrm{P}+\mathrm{CG})$, a large proportion of flashes (around 79\%) were included in sequences with at least two $\mathrm{CG}$ flashes separated by less than 2 s. Considering the time interval from the previous one and to the following one, the CG flashes were grouped into four distinct domains corresponding to isolated events and sequence phases, notably starting, development, and ending. A large majority of the first CG flashes of a sequence were positive $(65.5 \%)$, while a large majority of the last ones were negative $(63.2 \%)$. The $+\mathrm{CG}$ flashes differed from one domain to another in terms of peak current. The first $+\mathrm{CG}$ flash of a sequence had a much higher peak current than the last $+\mathrm{CG}$ flash of a sequence (ratio 1.84). From some case studies of such sequences including a large number of $\mathrm{CG}$ flashes, the distance between the flashes could reach several tens of kilometers and spread over the whole cloud area. This result shows a kind of synchronicity in the CG lightning activity, as shown by Yair et al. [2006], for several cells that are tens or hundreds of kilometers apart. From space optical observations, they observed that lightning occurring in one cell was immediately followed by lightning in another cell. They proposed an interpretation based on an analogy with coupled oscillators which could be applied for thunder cells embedded in an MCS. More recently, Yair et al. [2009b] studied a $1 \mathrm{~h}$ lightning activity in a thunderstorm by considering the times between consecutive $\mathrm{CG}$ flashes and their locations. They found that the lightning events clustered in several cells and that they occurred in sequences, even when they belonged to different cells. They suggested that the flash production of different cells of a thunderstorm was synchronized, and they proposed a model using a leaky integrate-and-fire concept in which the electric field variation following a flash is responsible for another flash. In the present case, we did not observe spatial clustering of the flashes, but we observed an obvious trend toward grouping in sequences for a large majority of them. Two interpretations are possible for these sequences.

[25] 1. The CG flashes in a sequence are produced after a strong first $\mathrm{CG}$ flash, most of the time positive, which neutralizes a large amount of charge which could create favorable conditions of flash triggering in another region of the cloud.

[26] 2. A complex propagation of leaders develops within the cloud, and several leaders could reach the surface and induce strokes several tens of kilometers away [Lang et al., 2004]. A more complete detection of the lightning activity is necessary to detect the possible propagation of intracloud lightning between charge regions across the stratiform region.

[27] Many sprites triangulated from a double cameradetection system were found to be shifted from their $\mathrm{P}+\mathrm{CG}$ flash by a distance of about 10 to $50 \mathrm{~km}$. In spite of the uncertainty of the location by triangulation, it is important to note that sprites shifted westward (downstream) of the $\mathrm{P}$
$+\mathrm{CG}$ flash stroke in a large proportion of cases. In several cases of $\mathrm{CG}$ flash sequences including a $\mathrm{P}+\mathrm{CG}$ flash, $-\mathrm{CG}$ flashes were also located on the western part of the cloud system. The mechanism suggested by such observations is that the $\mathrm{P}+\mathrm{CG}$ flashes could neutralize positive charges from cloud areas remote from their ground-strike points [see Neubert et al., 2008]. After this neutralization, the area could be negatively charged and favorable for - $\mathrm{CG}$ flash triggering.

[28] Acknowledgments. We thank Météorage for providing the data from EUCLID on the CG lightning flashes, and we thank MétéoFrance, the French weather service, for providing data from its radar network. We thank H.-D. Betz from the University of Munich for providing lightning location data from the LINET network. We also thank the Spanish MICINN for supporting this study under grant ESP2007-66542-C04-02.

\section{References}

Asano, T., M. Hayakawa, M. Cho, and T. Suzuki (2008), Computer simulations on the initiation and morphological difference of Japan winter and summer sprites, J. Geophys. Res., 113, A02308, doi:10.1029/ 2007JA012528.

Asano, T., T. Suzuki, Y. Hiraki, E. Mareev, M. G. Cho, and M. Hayakawa (2009), Computer simulations on sprite initiation for realistic lightning models with higher-frequency surges, J. Geophys. Res., 114, A02310, doi:10.1029/2008JA013651.

Barrington-Leigh, C. P., U. S. Inan, and M. Stanley (2001), Identification of sprites and elves with intensified video and broadband array photometry, J. Geophys. Res., 106, 1741-1750.

Bering, E. A., III, J. R. Benbrook, L. Bhusal, J. A. Garrett, A. M. Paredes, E. M. Wescott, D. R. Moudry, D. D. Sentman, H. C. Stenbaek-Nielsen, and W. A. Lyons (2004), Observations of transient luminous events (TLEs) associated with negative cloud to ground (-CG) lightning strokes, Geophys. Res. Lett., 31, L05104, doi:10.1029/2003GL018659.

Betz, H.-D., K. Schmidt, P. Oettinger, and M. Wirz (2004), Lightning detection with 3-D discrimination of intracloud and cloud-to-ground discharges, Geophys. Res. Lett., 31, L11108, doi:10.1029/2004GL019821.

Biswas, K. R., and P. V. Hobbs (1990), Lightning over the Gulf Stream, Geophys. Res. Lett., 17(7), 941-943.

Boccippio, D. J., E. R. Williams, S. J. Heckman, W. A. Lyons, I. T. Baker, and R. Boldi (1995), Sprites, ELF transients, and positive ground strokes, Science, 269, 1088-1091.

Boeck, W., O. Vaughan Jr., R. Blakeslee, B. Vonnegut, M. Brook, and J. McKune (1995), Observations of lightning in the stratosphere, J. Geophys. Res., 100(D1), 1465-1475.

Chanrion, O., et al. (2007), The EuroSprite2005 Observational Campaign: An example of training and outreach opportunities for CAL young scientists, $A d v$. Geosci., 13, 3-9.

Chen, A. B., et al. (2008), Global distributions and occurrence rates of transient luminous events, J. Geophys. Res., 113, A08306, doi:10.1029/ 2008JA013101.

Cummins, K. L., M. J. Murphy, E. A. Bardo, W. L. Hiscox, R. B. Pyle, and A. E. Pifer (1998), NLDN'95, A combined TOA/MDF technology upgrade of the US National Lightning Detection Network, J. Geophys. Res., 103, 9035-9044.

Frey, H. U., S. B. Mende, S. A. Cummer, A. B. Chen, R.-R. Hsu, H.-T. Su, Y.-S. Chang, T. Adachi, H. Fukunishi, and Y. Takahashi (2005), Betatype stepped leader of elve-producing lightning, Geophys. Res. Lett., 32, L13824, doi:10.1029/2005GL023080.

Fukunishi, H., Y. Takahashi, M. Kubota, K. Sakanoi, U. Inan, and W. Lyons (1996), Elves: Lightning-induced transient luminous events in the lower ionosphere, Geophys. Res. Lett., 23(16), 2157-2160.

Füllekrug, M., C. Price, Y. Yair, and E. R. Williams (2002), Intense oceanic lightning, Ann. Geophys., 20, 133-137.

Hayakawa, M., T. Nakamura, Y. Hobara, and E. Williams (2004), Observation of sprites over the Sea of Japan and conditions for lightninginduced sprites in winter, J. Geophys. Res., 109, A01312, doi:10.1029/ 2003JA009905.

Hayakawa, M., T. Nakamura, D. Iudin, K. Michimoto, T. Suzuki, T. Hanada, and T. Shimura (2005), On the structure of thunderstorms leading to the generation of sprites and elves: Fractal analysis, J. Geophys. Res., 110, D06104, doi:10.1029/2004JD004545.

Hobara, Y., N. Iwasaki, T. Hayashida, M. Hayakawa, K. Ohta, and H. Fukunishi (2001), Interrelation between ELF transients and ionospheric 
disturbances in association with sprites and elves, Geophys. Res. Lett., 28(5), 935-938.

Huang, E., E. Williams, R. Boldi, S. Heckman, W. Lyons, M. Taylor, T. Nelson, and C. Wong (1999), Criteria for sprites and elves based on Schumann resonance observations, J. Geophys. Res., 104(D14), 16,943-16,964.

Inan, U., C. Barrington-Leigh, S. Hansen, V. Glukhov, T. Bell, and R. Rairden (1997), Rapid lateral expansion of optical luminosity in lightning-induced ionospheric flashes referred to as 'elves', Geophys. Res. Lett., 24(5), 583-586.

Lang, T. J., S. A. Rutledge, and K. C. Wiens (2004), Origins of positive cloud-to-ground lightning flashes in the stratiform region of a mesoscale convective system, Geophys. Res. Lett., 31, L10105, doi:10.1029/ 2004GL019823.

Lyons, W. A. (1996), Sprite observations above the U.S. High Plains in relation to their parent thunderstorm systems, J. Geophys. Res., 101, 29,641-29,652.

Lyons, W. A., M. Uliasz, and T. E. Nelson (1998), Climatology of large peak current cloud-to-ground lightning flashes in the contiguous United States, Mon. Weather Rev., 126, 2217-2233.

Matsudo, Y., T. Suzuki, K. Michimoto, K. Myokei, and M. Hayakawa (2009), Comparison of time delays of sprites induced by winter lightning flashes in the Japan Sea with those in the Pacific Ocean, J. Atmos. Sol. Terr. Phys., 71(1), 101-111.

Mazur, V., X. Shao, and P. R. Krehbiel (1998), "Spider" lightning in intracloud and positive cloud-to-ground flashes, J. Geophys. Res., 103(D16), 19,811-19,822.

Miyasato, R., M. J. Taylor, H. Fukunishi, and H. C. Stenbaek-Nielsen (2002), Statistical characteristics of sprite halo events using coincident photometric and imaging data, Geophys. Res. Lett., 29(21), 2033, doi:10.1029/2001GL014480.

Miyasato, R., H. Fukunishi, Y. Takahashi, and M. J. Taylor (2003), Energy estimation of electrons producing sprite halos using array photometer data, J. Atmos. Sol. Terr. Phys., 65(5), 573-581.

Montanyà, J., O. Van der Velde, D. Romero, V. March, G. Sola, N. Pineda, M. Arrayas, J. L. Trueba, V. Reglero, and S. Soula (2010), High-speed intensified video recordings of sprites and elves over the western Mediterranean Sea during winter thunderstorms, J. Geophys. Res., 115 A00E18, doi:10.1029/2009JA014508.

Myokei, K, Y. Matsudo, T. Asano, T. Suzuki, Y. Hobara, K. Michimoto, and M. Hayakawa (2009), A study of the morphology of winter sprites in the Hokuriku area of Japan in relation to cloud charge height, J. Atmos. Sol. Terr. Phys. 71, 597-602.

Neubert, T., T. H. Allin, H. Stebaek-Nielsen, and E. Blanc (2001), Sprites over Europe, Geophys. Res. Lett., 28, 3585-3588.

Neubert, T., et al. (2005), Co-ordinated observations of transient luminous events during the EuroSprite2003 campaign, J. Atmos. Sol. Terr. Phys., $67,807-820$.

Neubert, T., et al. (2008), Recent results from studies of electric discharges in the mesosphere, Surv. Geophys., 29(2), 71-137, doi:10.1007/s10712008-9043-1.

Orville, R. E., and G. R. Huffines (2001), Cloud-to-ground lightning in the United States: NLDN results in the first decade, 1989-1998, Mon. Weather Rev., 129, 1179-1193.

Orville, R. E., G. R. Huffines, W. R. Burrows, R. L. Holle, and K. Cummins (2002), The North American Lightning Detection Network (NALDN)First results: 1998-2000, Mon. Weather Rev., 130, 2098-2109.

Parent-du-Châtelet, J., M. Guimera, and P. Tabary (2003), The Panthère Project of Meteo-France: Extension and upgrade of the French radar network, paper presented at 31st International Conference on Radar Meteorology, Am. Meteorol. Soc Seattle, Wash.

Pasko, V. P., U. S. Inan, T. F. Bell, and Y. N. Taranenko (1997), Sprites produced by quasi-electrostatic heating and ionization in the lower ionosphere, J. Geophys. Res., 102(A3), 4529-4562.

Pineda, N., J. Montanyà, O. van der Velde, and S. Soula (2008), Total lightning in a TLE-Bearing Winter Thunderstorm over the western Mediterranean, paper presented at 20th International Lightning and Detection Conference-2nd International Lightning Meteorology Conference, Vaisala, Tucson, Ariz.
Pinto, O., Jr., M. M. F. Saba, I. R. C. A. Pinto, F. S. S. Tavares, K. P. Naccarato, N. N. Solorzano, M. J. Taylor, P. D. Pautet, and R. H. Holzworth, (2004), Thunderstorm and lightning characteristics associated with sprites in Brazil, Geophys. Res. Lett., 31, L13103, doi:10.1029/ 2004GL020264.

Price, C., W. Burrows, and P. King (2002), The likelihood of winter sprites over the Gulf Stream, Geophys. Res. Lett., 29(22), 2070, doi:10.1029/ 2002GL015571.

Rakov, V. A., and W. G. Tuni (2003), Lightning electric field intensity at high altitudes: Inferences for production of elves, J. Geophys. Res., 108(D20), 4639, doi:10.1029/2003JD003618.

São Sabbas, F. T. S., D. D. Sentman, E. M. Wescott, J. O. Pinto, J. O Mendes, and M. J. Taylor (2003), Statistical analysis of space-time relationships between sprites and lightning, J. Atmos. Sol. Terr. Phys., 65, 525-536.

Seity, Y., S. Soula, and H. Sauvageot (2001), Lightning and precipitation relationship in coastal thunderstorms, J. Geophys. Res., 106(D19), 22,801-22,816.

Sentman, D. D., E. M. Wescott, D. L. Osborne, D. L. Hampton, and M. J. Heavner (1995), Preliminary results from the Sprites 94 aircraft campaign: 1. Red sprites, Geophys. Res. Lett., 22, 1205-1208.

Soula, S., O. van der Velde, J. Montanyà, T. Neubert, O. Chanrion, and M. Ganot (2009), Analysis of thunderstorm and lightning activity associated with sprites observed during the EuroSprite campaigns: Two case studies, Atmos. Res., 91(24), 514-528, doi:10.1016/j.atmosres. 2008.06.017.

Stanley, M. A., W. A. Lyons, T. E. Nelson, P. R. Krehbiel, W. Rison, and R. J. Thomas (2007), Comparison of sprite locations with lightning channel structure, Eos Trans. $A G U, 88(52)$, Fall Meet. Suppl., Abstract AE41A-07.

Takahashi, Y., R. Miyasato, T. Adachi, K. Adachi, M. Sera, A. Uchida, and H. Fukunishi (2003), Activities of sprites and elves in the winter season, Japan, J. Atmos. Sol. Terr. Phys., 65, 551-560.

Turman, B. (1977), Detection of lightning superbolts, J. Geophys. Res., 82(18), 2566-2568.

van der Velde, O. A., Á. Mika, S. Soula, C. Haldoupis, T. Neubert, and U. S. Inan (2006), Observations of the relationship between sprite morphology and in-cloud lightning processes, J. Geophys. Res., 111, D15203, doi:10.1029/2005JD006879.

Wood, T. G., and U. S. Inan (2002), Long-range tracking of thunderstorms using sferic measurements, J. Geophys. Res., 107(D21), 4553, doi:10.1029/2001JD002008.

Yair, Y., R. Aviv, G. Ravid, R. Yaniv, B. Ziv, and C. Price (2006), Evidence for synchronicity of lightning activity in networks of spatially remote thunderstorms, J. Atmos. Sol. Terr. Phys., 68(12), 1401-1415.

Yair, Y., C. Price, M. Ganot, E. Greenberg, R. Yaniv, B. Ziv, Y. Sherez, A. Devir, J. Bór, and G. Sátori (2009a), Optical observations of transient luminous events associated with winter thunderstorms near the coast of Israel, Atmos. Res., 91(2-4), 529-537, doi:10.1016/j.atmosres. 2008.06.018.

Yair, Y. Y., R. Aviv, and G. Ravid (2009b), Clustering and synchronization of lightning flashes in adjacent thunderstorm cells from lightning location networks data, J. Geophys. Res., 114, D09210, doi:10.1029/ 2008JD010738.

Yashunin, S. A., E. A. Mareev, and V. A. Rakov (2007), Are lightning $\mathrm{M}$ components capable of initiating sprites and sprite halos?, J. Geophys. Res., 112, D10109, doi:10.1029/2006JD007631.

O. Chanrion and T. Neubert, National Space Institute, Technical University of Denmark, DK-2100 Copenhagen, Denmark.

F. Gangneron, Y. Meyerfeld, J. Palmiéri, and S. Soula, Laboratoire d'Aérologie, UPS, Université de Toulouse, 14 Ave. Édouard Belin, F-31400 Toulouse, France. (sous@aero.obs-mip.fr)

F. Lefeuvre and G. Lointier, Laboratoire Physique et Chimie de l'Environnement, F-45071 Orléans CEDEX 2, France.

J. Montanyà and $\mathrm{O}$. van der Velde, Electrical Engineering Department, Technological University of Catalonia, E-08222 Terrassa, Spain. 